\title{
The environment and materials, from the standpoints of ethics, social sciences, law and politics ${ }^{2 / 2}$
}

\author{
Jean-Pierre Birat ${ }^{*}$ \\ IF Steelman, Semécourt, France
}

Received: 24 May 2018 / Accepted: 12 December 2018

\begin{abstract}
Materials are deeply connected with the environment, because they stem from raw materials extracted from the geosphere, rely on large amounts of energy and of water in their production stage, project emissions to air, water and soil when their ores (or minerals) are mined, when they are made in steel mills or cement kilns, including very significant amounts of greenhouse gases. They also contribute to emissions and energy consumption of the artifacts of which they are part, either consumption or investment goods. Their connection with the biosphere raises many issues, in terms of toxicology, ecotoxicology or biodiversity or simply of public health or in the working place. Materials, as an essential part of the anthroposphere, interact deeply with the anthroposphere itself but also with the biosphere, the geosphere, the atmosphere and the hydrosphere, thus with nature in a general way through mechanisms which can no longer simply be described at the margin, as resource depletion or as pollution. This raises issues related to the sustainability of materials in human activities, in which they are deeply immersed and entangled. The standard way of dealing with these environmental issues is to invoke sustainability and to explain that all actors are engaged in sustainable development, a morals or an ethics that points in which direction to go: all players in the materials field, industry, institutions and research, claim allegiance to sustainable development. At a more technical level, specific tools like Life Cycle Assessment (LCA) are used extensively to measure the interaction of materials with the environment. This, however, is not enough to deal properly with the environmental issues of materials, because these issues are not marginal any longer: the anthroposphere has become so large with respect to the biosphere, the geosphere and the planet in general that environmental risk is now part of modern life, especially in connection with climate change and the loss of biodiversity. To go deeper in analyzing the connection of human activities with nature, it is therefore necessary to reach out to SSH (Social Science and Humanities) disciplines and particularly to environmental ethics. This is a prerequisite for materials scientists (and others) to act decisively in the future in the face of the danger that lies ahead of us. The present paper reviews the advances of environmental ethics, a fairly young discipline born in the 1970s, in as far as it can help all actors on the world anthropospheric theater choose their lines for the future in a more conscious and sophisticated way than simply claiming obedience to sustainability. We will review briefly intellectual forerunners of the discipline like Jean-Jacques Rousseau, Henri David Thoreau, Rachel Carson or Paul Ehrlich. This will help flesh out well-known concepts like the precautionary principle or the "polluter-pays" principle, which are invoked in creating new materials or new processes to keep pollution and health issues under control, as part of the constraints of professional ethics but also of environmental law. It will be necessary to question to whom or to what the key concept of intrinsic value is attached: people, all living organisms or ecosystems, i.e. the environment in general, and thus to define anthropocentrism, biocentrism and ecocentrism. Environmental law and the ethics of sustainable development are still mainly anthropocentric while scientific ecology is more clearly ecocentric. To tackle the challenges of environmental issues as they are posed today and to avoid catastrophes, it might be necessary in the future for all social players and for people of the world of materials to follow the steps of environmental ethics and to move up from anthropocentrism to the broader vision of ecocentrism.
\end{abstract}

\footnotetext{
Paper given as a keynote lecture to the 12th Society and Materials Conference, Metz, 23-24 May 2018

* e-mail: jean-pierre.birat@ifsteelman.eu
} 
Keywords: materials / production of materials / use of materials / raw materials and circular economy / ecological footprint of materials / pollution / "polluter-pays" principle / sustainable development / precautionary principle / waste hierarchy / environmental issues / LCA / MFA / theory of risk / environmental ethics / anthropocentrism / biocentrism / ecocentrism / environmental law

Résumé. L'environnement et les matériaux, vus des points de vue de l'éthique, des sciences sociales, du droit et de la politique. La relation entre matériaux et environnement est très forte : en effet les matériaux trouvent leur origine dans les matières premières issues de la géosphère, dépendent de grandes quantités d'énergie et d'eau dans l'étape de leur production, projettent des émissions dans l'air, l'eau et le sol quand leurs minerais (minéraux) sont extraits des mines ou des carrières, quand ils sont produits dans des usines sidérurgiques ou des cimenteries - et ces émissions comprennent des gaz à effet de serre. Les matériaux contribuent aussi aux émissions et aux consommations d'énergie des artifacts auxquels ils sont intégrés, comme biens de consommation ou d'investissement. Leur rapport avec la biosphère soulève aussi beaucoup de problèmes en termes de toxicologie, d'écotoxocologie et de biodiversité ou simplement de santé publique ou au travail. Les matériaux, qui jouent un rôle essentiel dans l'anthroposphère, interagissent avec l'anthroposphère elle-même, mais aussi avec la biosphère, la géosphère, l'atmosphère et l'hydrosphère, donc avec la nature dans sa totalité à travers des mécanismes qu'on ne peut plus simplement décrire à la marge comme épuisement des ressources ou comme pollution. Les questions posées relèvent du caractère durable des matériaux dans l'activité humaine, où ils sont immergés et avec laquelle ils sont intriqués. La façon habituelle de traiter de ces questions environnementales est d'invoquer le développement durable et de montrer que tous les acteurs y sont engagés, dans une démarche à la fois morale et éthique qui donne la direction vers laquelle aller: dans le monde des matériaux, tous les acteurs industriels, institutionnels ou de la recherche ont fait allégeance au développement durable. À un niveau plus technique, l'analyse de cycle de vie (ACV) est utilisée très couramment pour mesurer la force de l'interaction entre matériaux et environnement. Ceci ne suffit cependant pas pour traiter convenablement des questions environnementales liées aux matériaux, parce qu'on n'a plus à faire à des questions marginales : l'anthroposphère a acquis une dimension si grande par rapport à la biosphère, la géosphère et la planète en général que le risque environnemental est devenu une part importante de notre monde moderne, en particulier en ce qui concerne le changement climatique et la perte de la biodiversité. Pour aller plus loin, il est nécessaire de faire appel aux sciences sociales et humaines (SSH) et en particulier à l'éthique environnementale. C'est un préalable pour que les spécialistes de matériaux (et beaucoup d'autres acteurs) puissent agir avec détermination dans l'avenir et faire face aux dangers qu'ils confrontent de façon durable. Cet article passe en revue les avancées de l'éthique environnementale, une jeune discipline apparue seulement sous sa forme actuelle dans les années 1970, qui devrait suggérer aux acteurs du théâtre de l'anthroposphère les textes et les dialogues à déclamer dans l'avenir : ils s'engageront ainsi d'une façon plus profonde et plus complexe qu'en se déclarant simplement adeptes du développement durable. On parlera aussi des écrivains-précurseurs qu'ont été JeanJacques Rousseau, Henri David Thoreau, Rachel Carson ou Paul Ehrlich. Cela permettra de donner de la consistance au principe de précaution ou à celui du pollueur-payeur, qu'on invoque à propos d'innovation en procédés et en produits pour en maîtriser les conséquences en matière de pollution et de santé publique. Il s'agit de cesser de les évoquer comme des mantras et de leur donner une épaisseur à la fois d'éthique professionnelle et de respect du code l'environnement. La question-clé est de savoir à qui ou à quoi on doit attribuer une valeur intrinsèque : les gens, les êtres vivants en général ou les écosystèmes, ce qui conduit à définir l'anthropocentrisme, le biocentrisme ou l'écocentrisme. Le code de l'environnement est aujourd'hui anthropocentrique, alors que l'écologie scientifique est très clairement écocentrique. Pour affronter les défis que posent les questions environnementales, à la société en général mais aussi aux acteurs du monde des matériaux, il sera probablement nécessaire dans l'avenir de suivre les pas de l'éthique environnementale et de passer d'une vision purement anthropocentrique du monde à une vision plus large, donc à une vision écocentrique.

Mots clés: matériaux / production de matériaux / utilisation des matériaux / matières premières et économie circulaire / empreinte écologique des matériaux / principe du pollueur-payeur / développement durable / principe de précaution / hiérarchie des déchets / questions environnementales / ACV / AFM / éthique de l'environnement / anthropocentrisme / biocentrisme / écocentrisme / code de l'environnement

\section{Foreword}

"All this inability to act effectively in the political arena casts a long shadow of doubt on whether, politically or technologically, much less ethically, we humans are anywhere near being smart enough to manage the planet"

Rolston [1]
Materials are at the core of our modern world, where the domain of people and society, the anthroposphere, has reached a larger extension than ever before in history. The anthroposphere interacts on an equal footing with the spheres of nature, i.e. the biosphere, the geosphere and the atmosphere and thus the anthroposphere is no longer today 
immersed in nature but is partially in control of it. This is an echo of what Bruno Latour says in [2], pointing out the fact that these interactions are reciprocal.

Materials themselves play a complex role in this interaction: they enforce the barriers between the spheres and make the life of humans more comfortable or even possible; they also contribute to emissions and pollution, directly where materials are produced and indirectly through the artefacts that are made of them; finally, they borrow from the limited amount of "fossil" resources available, either energy or raw materials [3].

The fate of the environment is therefore entangled with that of artifacts and of materials, and vice-versa: for example, the steel industry is directly responsible for roughly $7 \%$ of greenhouse gas emissions, themselves the major cause of anthropogenic climate change.

Materials scientists and engineers can no longer operate solely in the isolated world of Materials Science. Indeed, they have to be deeply aware of how materials production interacts both with society and nature. Process engineers develop new or better processes for making materials, which are now tailor-designed to minimize their environment footprint in an approach called ecodesign or lean and frugal design. New products, today, can only be commercialized after a series of studies have been performed, which measure the material's interaction with society, people and nature: this includes Life Cycle Analysis (LCA), Impact Assessments, Sustainability Assessments (SAT), Materials Flow Analysis (MFA), toxicological and ecotoxicological studies as well as, sometimes, social science studies, for example in the framework of Social Innovation [4].

This broader dimension of materials science is reflected regularly in the papers published in Matériaux et Techniques, especially the annual special issue related to the Society and Materials conferences (SAM) [5-9]. Moreover, the author has a book in print entirely devoted to this broad topic [10].

The environmental and societal dimensions are often simplified by referring to Sustainable Development or by using a specific tool like LCA.

This, however, is too narrow a perspective, as the ultimate approach should question the connection of materials with nature and society at a more complex level of argument, for example that of ethics and philosophy.

All things considered, materials are social constructs [11], and the environment is an important element of this construction. However, this idea is difficult to grasp for "hard scientists" and some explaining and arguing, like what is done here, is necessary.

This article was written for materials scientists and engineers, especially those who have been working on environment-related issues and have not always had an opportunity to dig into the concepts at the background of their work.

Therefore, the present article is not out of place in a journal like Matériaux $\&$ Techniques. This may be going against the habit of keeping disciplinary fields separate, especially hard and soft sciences, even more so metallurgy and ethics or philosophy, but the tradition of Society and Materials conferences has been to break interdisciplinary silos [12]. SSH itself is ripe with new approaches, which question the way science and technology function and do it in a deep and unsettling way. For example, the environment itself is considered today as a social construct like materials.

\section{More on the connection between materials, materials scientists and the environment}

Material scientists have been using the concept of Life Cycle Thinking (LCT), in connection with their use of LCA but also, more profoundly, because this has been a way to acknowledge that materials have a time and space extension that goes well beyond simply making or using materials.

This is a way of embedding materials into an extended reality, which is not that of a virtual world but rather of the total world of the environment and of society as a whole, especially the value chains in which materials are involved. LCT leads to the concept of circularity, of circular economy, a systemic approach in which materials have been deeply active for a long time, actually for longer than the word has become popular in policy making circles [13]: the circular model has been the historical model for structural materials throughout history and even prehistory [14], thus for copper, bronze, iron, tin, stones and even wood; more recently, the materials community has been active in fleshing out circularity in practical accomplishments, around the concept of recycling, reuse, exchange of waste between different industrial activities (called today industrial synergy), etc.

An effective search for materials and energy efficiency as well as ecodesign approaches that include lean and frugal design have been particularly active, earlier and to a larger extent than in other industrial activities. This points to a genuine commitment to the environment, in the sense of countermeasures being actively implemented in plants and incorporated into the business model of materials industries [3]. This has even led to the conclusion that caring for the environment, from an industrial standpoint, is often a way to improve its own processes and to become more efficient: the optimum for the whole environment is often also an optimum for the industrial ecosystem.

At a societal level, LCT has improved communication across the value chain, in effect forcing chains of clientsusers to exchange data regarding the products they trade: these are the figures that populate the LCA databases but also the LCI (Life Cycle Inventory) of particular studies. Note, incidentally, that materials play an essential role in these databases. 
The circular economy, an essential concept today in the implementation of sustainable development by policymakers, is therefore a practice of the materials world and of materials people that has served as a model to society in general and one in which the materials community is fluent.

The further concept of Social Cycle of Materials was proposed by sociologists to describe how materials innovation takes place and by focusing on the social actors, which intervene in the process [15]: "we might initially think of 4 types of actors that are fully part of the social cycle of materials, inasmuch as they have a great importance in producing social and economic impacts in a broad sense and influence the development of materials. These actors include those who belong to the world of scientific and technological research, those involved in the management of environmental dynamics, those involved in the design and implementation of policies, and what we commonly refer to as civil society (quote from [16])". The point of extending LCT through a critical analysis external to the domains of LCA and of technology, is to go beyond what the discipline can offer from its own methodological resources, particularly as far as externalities (like environmental issues) are concerned, as well as risks.

More generally, materials scientists have a role that goes way beyond inventing new materials, new processes for making them and certifying their sustainability by an LCA study: they are part of the social network that needs innovation in their field, that specifies it in a long and interactive dialogue and that arrives at solutions which all players deem acceptable, from various standpoint, including environmental ones. The materials people themselves are thus part of the Social Cycle of Materials, volens, nolens.

In other words, materials people have been using environmental ethics for a long time, but à la Monsieur Jourdain [17]. A deeper, more focused look at the discipline, as proposed in the present article, can only help them go further in that direction.

\section{Positioning materials and the spheres of ecology in an historical and philosophical perspective}

The questions with which this article deals are related to a number of almost synonymous words-nature, environment, natural environment, ecology and ecosystems.

They also refer to a series of methodological approaches natural philosophy, sustainability, environmental damage, human/non-human health (toxicology, ecotoxicology), $\mathrm{SSH}^{1}$ (sociology, anthropology, geography, philosophy) and to disciplines which tackle the same objects from different standpoints-philosophy, ethics (environmental ethics), political science related to the environment and law. Time is also of the essence, as each of these concepts and methods are dated, "time-stamped", and have been changing

\footnotetext{
${ }^{1}$ Social Sciences and Humanities.
}

not only with time but also with space-New Zealand, for example, has environmental laws which deconstruct the basis of the environmental laws of Judeo-Christian countries $[18]^{2}$

Another entry into this discussion would have consisted in mentioning and analyzing the contributions of important authors who have exposed paradigm shifts in concepts and approaches related to Environmental Issues (EI) before others did it or who have done it better than them-thus in collecting a kind of anthology. An interesting book of Ariane Debourdeau does exactly that [19]. Authors which share the status of writers and philosophers, like Jean-Jacques Rousseau [20] or Henry David Thoreau [21] among many others, would have an important role in such an anthology alongside more abstract and intellectual authors.

After personally working on countless environmental issues related to materials and publishing widely on many of them as an engineer and a scientist [10], I felt the need for a more rigorous and tightly argued approach regarding the intellectual arguments on which environmental issues are analyzed and judged. I wanted to question the historical background of which I was distinctly part, as most of the structured work in the area goes back to the 1960s and 1970s, the philosophical and ethical backgrounds on which all of this is based and their connection with the formulation of environmental law. Leading experts in these various fields operate in separate conceptual worlds so that explaining their advances, which are not fully coherent, is a challenge.

Therefore, we will start by reviewing the key words on which this article is structured: nature, natural science, environment, wilderness, ecology and their daughter categories of natural/scientific ecology, ecosystems and biosphere, industrial ecology and anthroposphere.

Then we will mention the methods and keywords of various practical ways for thinking and acting about the environment: natural science in the past, sustainability, the precautionary principle, the principle of responsibility or the "polluter-pays" principle nowadays, the connections with pollution, environmental damage, health and toxicology.

Finally, in order to try to put everything into a more coherent focus, we shall review philosophical and ethical views about the environment, which are tightly connected with political science and environmental law. However, as it turns out, philosophers and ethicists went further than what society is ready to implement, as exemplified by the present status of environmental legislation, which remains somewhat behind ethical thinking.

Ironically enough, what we will be able to review is strongly eurocentric, focused on the work developed in Western countries and it ignores some of the thinking common in non-western cultures, especially the cultures of the First Peoples.

\footnotetext{
The river Whaganui was recognized as a living entity by the Parliament of New Zealand on 15 March, 2017.
} 


\section{Keywords: Nature, Environment and Ecology}

Nature is probably the oldest word that relates to the topic of this article, along with the adjective natural and other composite words. ${ }^{3}$

The word Nature comes from latin natura, which is derived from the verb nascere, to be born, and therefore means the action of giving birth, of extracting, of being innate or "natural". It also means "the way things are", the order of things, like in the Natura Rerum of Lucretius. It is actually the translation by Lucretius of old Greek $\phi v \sigma \iota \kappa \dot{\eta}$, or physics. It corresponds to what is called the natural world today, formally studied by Natural Sciences (sciences naturelles, F), which are nowadays subdivided in Life Sciences, Earth Sciences and Physical Sciences, to keep things simple.

Natural Science, in the singular, designated in Antiquity what is called today Science on the one hand and Philosophy on the other.

The word environment is a much more recent word, when it is used in a sense close to what we mean here - a set of elements and of physical phenomena which influence a living organism, 1827 in English and 1921 in French, although its present use-ensemble des conditions naturelles et culturelles susceptibles d'agir sur les organismes vivants et les activités humaines - goes back only to c.1960 [22]. Note that both keywords, nature and environment, are sometimes used together, as in the expression natural environment, which is therefore tautological.

The word ecology brings the theme under the category of science: it stems from the German word Ökologie, itself

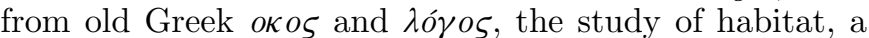
word made up by Ernst H. Haeckel (1873), a medical doctor and biologist who specialized in zoology and anatomy. An earlier occurrence is mentioned in Henry David Thoreau (1852), although it went unnoticed at the time [23]. As a science and until 1968-1970, ecology described the milieus where living organisms lived: then a metonymic shift gave the word the meaning of what is studied by ecology. Nowadays, the meaning has been extended to that of a discipline related to policymaking, which has the objective of better adapting man to his environment. The word also designates the political movements that support this practice.

At the core of this article is therefore an old concept, Nature, which has been present in human thought since Antiquity: in the Western tradition, Nature was conceptualized and defined by Greek philosophers, while monotheist religions were at the origin of the slightly different Judeo-Christian tradition. The attention to environmental issues, however, is much more recent: indeed, the modern meaning of the words environment and ecology dates back to the turn of the 1970s.

Appendix A gives the equivalents of some essential keywords of this article in a few major languages (English, French, German, Spanish, Chinese and Japanese).

\footnotetext{
3 The American Heritage Dictionary of the English language lists 27 words related to nature and natural.
}

\section{Essential environmental concepts}

In this section, we introduce the environmental issues at the core of this article.

\subsection{Identification of "environmental issues": pollution and environmental damage, resources and resource depletion, ecosystems and biodiversity}

Environmental Issues (EIs) were identified in the second half of the 20th century and became common lore, in the press and in political discourse, when they started to become worrisome. Beyond the words and the stories that they told, there developed an understanding of their mechanisms, consequences and causes: a science of the environment took shape, complete with models, measurements and simulations. It consisted actually in the convergence of many disciplines, from physical and life sciences to SSH - including a number of applied disciplines, like meteorology or mining technology. On the other hand, issues clearly mean problems and the emphasis was put on the liabilities related to the environment and to their negative externalities, to use economic language.

Pollution of air, water and ground was probably the first of these issues to show in the spotlight. Initially a local matter, often related to an industrial plant, it has evolved into a regional and even a worldwide matter, caused by industry but also by households, traffic and agriculture, sometimes with interactions between these different origins through the transport of pollution across regions, borders and even continents. Water pollution has affected water tables, whole watersheds, seas and oceans. Ground pollution tends to be more local but can contaminate water and thus be transported far away. Pollution can result in environmental damage such as smog or particulate matter in the lower atmosphere, especially in cities. Greenhouse gas emissions, not strictly considered as air pollution, belong to the same class of phenomena: they are clearly connected to Climate Change, one the major environmental issues today.

Resources, both in energy and raw materials, which were extracted from the ground in mines, quarries, oil or gas fields, also joined the list of environmental issues, when the matter of their possible scarcity was raised and the concept of Critical Raw Materials (CRM) started to be used. Besides primary raw materials, secondary raw materials and the concept of the circular economy became important in the discussion of the availability of materials resources.

Ecology made the point that these issues could not be analyzed separately and purely locally but were connected inside the whole biosphere, where the unit set of reference is an ecosystem or a set of ecosystems (biomes) and actually the whole anthroposphere, where the industrial ecology model describes it metaphorically as a natural system. Interaction of both spheres at a global scale, for example in the case of the ozone layer destruction, of climate change and of the mass extinction of biological species (biodiversity), became the norm in addressing these issues. The awareness of the importance of environmental issues at a political level reached the scale of the planet and, therefore, 


\section{SUSTAINABLE DEVELOPMENT

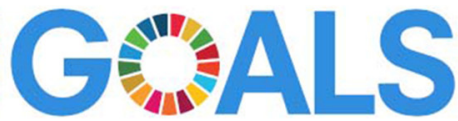

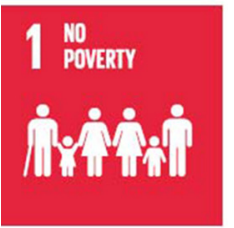
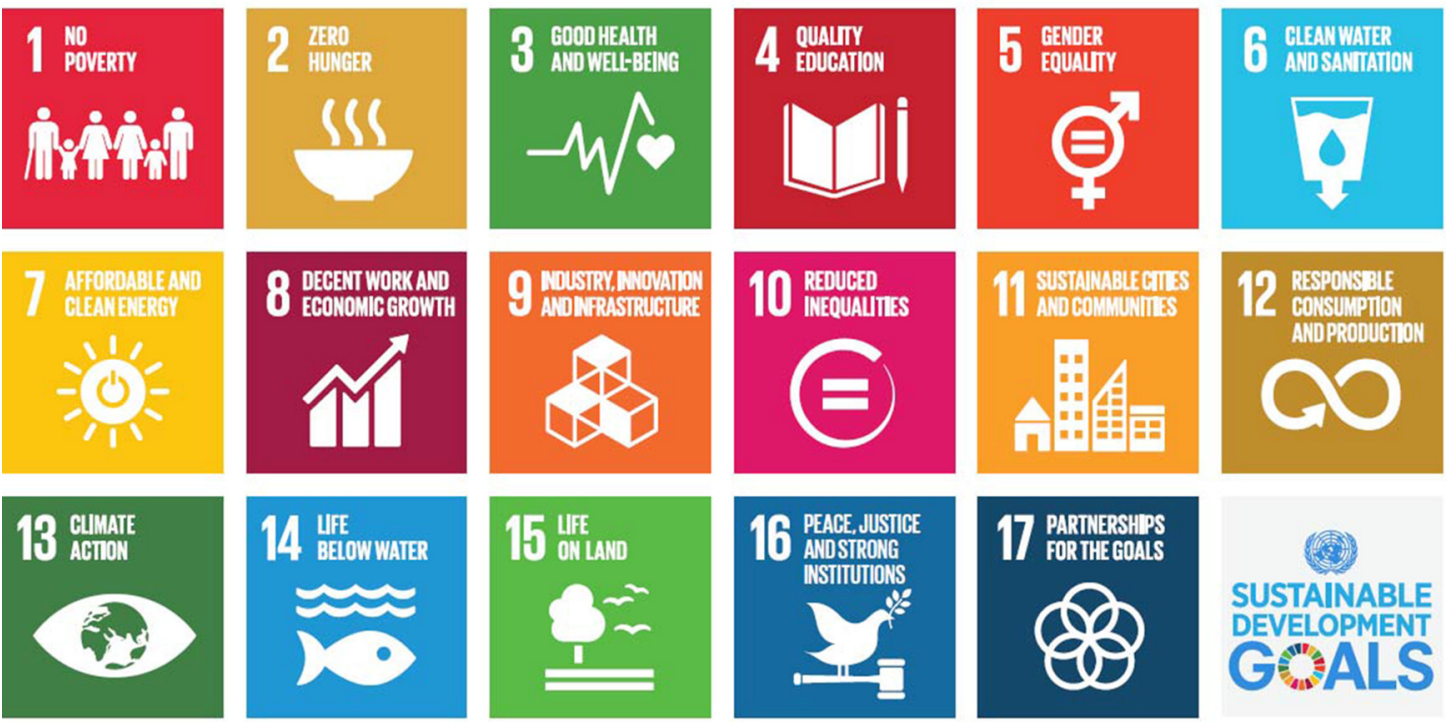

SUSTAINABLE DEVELOPMENT GALS

Fig. 1. The Sustainable Development Goals of the UN.

Fig. 1. Les objectifs de développement durable de l'ONU.

international organizations, foremost of which the United Nations and its various bodies, took the issues in stride and developed policy approaches for the world as whole to address them.

The SSH dimension of environmental science gave the floor to philosophers, to analyze, dissect and clarify the key concepts, but also to ethicists, who argued about responsibility and moral values, and finally to political scientists and policy makers who proposed frameworks for steering the world through these issues and beyond the crisis looming in their trail. These contributions will be presented in Section 5.4.

\subsection{Construction of the concept of sustainability}

The major concept around which these issues have been packaged in global communication and in policymaking circles is that of Sustainable Development, also called Sustainability. There are various definitions of sustainability but the UN version promises that the planet will be transmitted to future generations in such a way that they can continue to live on it under conditions that guarantee a reasonable level of wellbeing. This is certainly not an objective statement of what will undoubtedly happen, but rather an ethical objective that should guide policy in the future and a kind of contract between the present and the future.

Note that Sustainability is related to the precautionary principle, to the "polluter pays" principle and to the general acknowledgment that we live in a society of risks. All these concepts were contributed by philosophy, environmental ethics and environmental policymaking (cf. Sects. 6.4, 6.5, 6.6 and 7 ). They are close but not fully congruent, nor necessarily coherent: they relate to various forms of analysis, of storytelling, and, as such, all of them are "true".

\subsection{Damage to human health and to non-human health-toxicology and ecotoxicology}

Human health relates to a particularly complex interface between biosphere and anthroposphere: a sustainable world is one in which human health is preserved. This is related to sanitation, medicine, advances in biology and pharmacology. This is also related to toxicology and to the twin discipline of ecotoxicology, which extends the concept of health to non-human species.

The UN, in its Sustainable Development Goals, has an extended definition of sustainability which includes not only environmental and health provisions but also cultural values related to well-being in general, end of poverty, democracy, peace, gender equality, etc. (cf. Fig. 1).

\subsection{Environmental policymaking, law and legislation}

The policymaking dimension of sustainability, considered today as the main formulation of the response to environmental issues, has developed across society in the worlds of government, business, associations (NGOs) and citizenry.

Law has also contributed to proposing frameworks for reining in environment issues in as far as they raise specific and important problems that need legal resolution.

\section{Disciplinary approaches to the environment}

We shall now move on to the construction of the relevant concepts, from the standpoints of more structured disciplines, namely philosophy, ethics and law. 


\subsection{Natural philosophy and the separation of science from philosophy}

Until Galileo Galilei and his trial in 1633, science and philosophy were not separated and the study of both was called natural philosophy, philosophia naturalis in Latin. Philosophers, as they are remembered today, were also scientists and engineers, to use modern terminology. Natural philosophy was to be distinguished from moral philosophy, which included metaphysics and ethics as well as what is called today SSH.

Representative productions of natural philosophy are the Natura Rerum of Lucretius [24] or the Natural History of Pliny [25], while the more philosophical texts would be represented by Aristotle's Physics [26].

There are many ways beyond physics and philosophy, in which nature intruded on human consciousness. Meteors and the weather, water, rain, sea and rivers, landscapes either in the tame countryside of farmers, in the sophisticated gardens of the aristocracy or in the wilderness of mountains or of virgin regions of the world. Interest was in the quiet or in the extravagant occurrence of the weather, like storms, floods, tempests. This is now studied for example by historians, in a discipline called the History of emotions [27].

In the Middle Ages, the world was seen in Europe as an impersonation of the world of the Bible: meteors expressed the power and the anger of God, while the Devil was hiding in the mountains [28].

Modern times saw the desacralization of nature during the Renaissance, which is understood by historians today as the rediscovery of nature rather than that of Antiquity ${ }^{4}$. Nature became a mirror of people's minds, moods, feelings rather than that of godlike creatures [29-33]. Note that the Counter Reform of the catholic church helped people look up to the sky, which had become abundantly represented in frescos showing it as populated by angels (cf. Giambattista Tiepolo, for example).

Rather than tracking the philosophical analysis of nature in Modern Times, we will simply mention some of the writers and plastic artists, who have illustrated the evolution of the vision of nature. Indeed, artists are members of society, who are the first to express how people feel about nature in powerful and original ways.

Jean-Jacques Rousseau (1712-1778) spoke of his own introspective feelings as if they were a form of weather - he vies "to apply a barometer to his soul" ${ }^{5 "}$ " [20] - and he used his walks (promenades) in the countryside or in city parks to clarify his own thoughts. That was the time when aristocrats started to be interested in nature and actually traveled to the mountains, like the Alps in France, driven

\footnotetext{
${ }^{4}$ Knowledge, as taught in secondary schools from Antiquity to the beginning of the Renaissance, was subdivided in the seven Liberal Arts. The Artes Liberales comprised the Trivium (the three ways) related to the power of language (grammar, dialectic and rhetoric), and the Quadrivium related to the power of numbers (arithmetic, music, geometry ad astrology (or astronomy). Overarching them was Philosophy and Theology, towards the end of the Middle Ages.

5 «J'appliquerai le baromètre à mon âme. ».
}

by the emotion of the "sublime", that it offered to bored city dwellers. Emmanuel Kant (1724-1804) defined the sublime in his theory of aesthetics: the sublime goes beyond the beautiful or the pretty and opens up a dimension that is limitless, infinite.

Note that Rousseau used the concept of nature to build his own vision of society: nature is the reference state (l'état de nature) from which the organization of society is constructed through his concept of a Social Contract, concluded among its members, whereby some of their freedom is abandoned in exchange for the protection of other intrinsic rights $[34]^{6}$. The Social Contract has been at the basis of political theory since then, although mostly in a general way, since Rousseau's ideas have been seen since as too simplistic both by anthropologists [35] and political scientists. It is still used today, however, to conceptualize what ought to be the connection between society and nature (cf. Sect. 6.5 and [36]).

Henry-David Thoreau (1817-1862) is an American philosopher and writer, who left the city of Concord, Massachusetts, to live in a cabin by a lake for one year and wrote a book depicting his experience, Walden or the life in the woods [21]: he is considered as one the first "inventors" of ecology as a science and at the same time as a philosopher. The following quote from Walden summarizes his attitude: "I went to the woods because I wished to live deliberately, to front only the essential facts of life. And see if I could not learn what it had to teach and not, when I came to die, discover that I had not lived". He introduced the concepts of the preservation of nature in the countryside and of the conservation of wilderness in national parks, an institution invented in the US in 1972 by President Ulysses Grant: the principle of national parks was adopted across the world as a way to create living museums which preserve nature, as a kind of Paradise Lost, a reminiscence of the Biblical, Judeo-Christian vision of nature and the world. Other important authors were instrumental in the development of the American wilderness concept: John Muir (1838-1914), the founder of the Sierra Club and the proponent of reverentialism, and Aldo Leopold, who had advocated an appreciation and conservation of things natural, wild and free (the land as a whole ought to be an object of our moral concern), and then the adoption of a land ethics [37].

Closeness to nature was an important part of romanticism, strong in the areas of poetry, plastic arts, music and novels: it was born as a reaction to the industrial revolution and to the rationalism of the Enlightenment.

Nature in all these instances represents the world as it is, in all its dimensions and complexity, and includes man, mankind and society. Thus, nature is not simply the world without people and without the artificial contributions that they made. The vision of nature has been increasing in complexity under the dual input of sciences and arts from the onset of Modern Times until today.

Note for the record, that at the end of 19th century, science was so certain of its ability to describe the functioning of the world that the connection with

\footnotetext{
${ }^{6}$ His thoughts were based on Thomas Hobbes' and John Locke's previous work.
} 
philosophy, arts and literature was inversed: a school of thought called naturalism became popular among novelists - the foremost of whom was Emile Zola ${ }^{7}$, painters and other plastic artists ${ }^{8}$, who referred either to naturalism or to realism, taken as synonyme; a philosophical school of thought also bearing the name of naturalism ${ }^{9}$. Nature, in these contexts, means the world as it functions in all its complexity and therefore includes the whole biosphere, the anthroposphere and the geosphere-although none of the naturalists knew these words or the concepts they cover: nature as the world outside of mankind's influence is therefore not part of naturalism. Naturalism includes mankind, society and social sciences, although the ideas at the times would not be considered as part of SSH today but more as ideologies: for example, Social Darwinism or Eugenism developed as branches of Naturalism.

The Naturphilosophie of Friedrich von Schelling (17751864) in Germany is somewhat related to philosophical Naturalism and is an attempt to unify material and spiritual phenomena under the aegis of nature. Based on Johann Goethe's romantic ideas, it is a kind of pantheist religious endeavor dressed in philosophical garments.

\subsection{National parks and the appeal of wilderness}

National parks are a 19th century concept, initiated in the United States, as a kind of penance for colonization of North America and to avoid artificializing landscapes there, like what had happened in Europe. It is interesting to note that the concept of responsibility to future generations, which is at the core of sustainability, comes from this practice.

Thus, the Organic Act of 1916 says that the National Park Service was created "to conserve the scenery and the natural and historic objects and wildlife therein, and to provide for the enjoyment of the same in such manner and by such means as will leave them unimpaired for the enjoyment of future generations [38]". More recently, President Lindon Johnson said: "If further generations are to remember us more with gratitude than sorrow, we must achieve more than just the miracles of technology. We must

\footnotetext{
$\overline{{ }^{7} \text { He claims that literature should become scientific in the preface }}$ of Thérèse Raquin and in Le roman experimental. He gets his intuition from Claude Bernard, a biologist (La méthode expérimentale) and from Auguste Comte, a philosopher who created Positivism. Other notable French writers, who joined this movement, are Guy de Maupassant, Gustave Flaubert, Joris-Karl Huysmans and Alphonse Daudet. Naturalism diffused to Italy (Giovanni Verga), Spain (Benito Pérez Galdós), latin América (Clorinda Matto de Turner) and Quebec (Albert Laberge).

${ }^{8}$ Gustave Courbet is considered as the initiator of the Realism school (the Bonjour Monsieur Courbet painting). His work was reacting to Romanticism and to the academic style preferred in the Salons.

${ }^{9}$ Philosophical Naturalism states that anything that can be known about the world stems from "natural principles". There are no external causes to things or phenomena beyond those that the best modern science can describe. Thus, there is no transcendence.
}

also leave them a glimpse of the world as it was created, not just as it looked when we got through with it' (mentioned at the Bryce Canyon National Park).

National Parks developed all over the world under the aegis of the International Union for Conservation of Nature (IUCN), created as an offshoot of UNESCO in 1948 [39]. There are thousands of parks in 100 countries today [40].

National parks, as explained when mentioning Thoreau, refer to the concept of wilderness, which is itself related to the concept of climatic climax landscapes, a historical concept based on the idea that nature, if left alone and pristine, functions in steady-state and preserves in a kind of untouched, virgin way. Modern ecology does not believe in this idea any longer.

Mutatis mutandis, wilderness is a kind of social value similar to the cultural dimension of biodiversity.

\subsection{Critical events and critical writings}

We have thus far insisted on the point that environmental issues are understood today as having reached a peak and entered into a phase of crisis and even a feeling of incoming doom. The list of environmental issues is fairly well identified (cf. Sect. 5.1). The tipping point is acknowledged as the early 1970 s.

There were a number of critical writings, which acted as early announcement of that incoming crisis, as a kind of whistleblowers of deep societal changes to come.

In France, René Dumont published books in the early 1960s, which foretold of a food crisis, especially in the Third World and in poor countries [41]. The Green Revolution proved him wrong, hic et nunc, and he is now mostly forgotten, including in the world of political ecology in France, where he was the first green party candidate to presidential elections (1974). But he helped raise awareness of EIs.

In the English language literature, Silent Sprint of Rachel Carson (1907-1964) [42] and The Population Bomb of Paul R. Ehrlich (1932) and Anne Ehrlich [43] are recognized as the most influential early texts that sounded the bell of doom. Rachel Carson, a marine biologist, attracted attention to the dangers of pesticides like DDT in her poetically written book and led the US government to create the Environmental Protection Agency (EPA). Paul Ehrlich was a biologist who worked in the field of demography and is famous for the IPAT equation, which he developed with Paul Holdren [44]: he warned that population growth would let pollution get out of control. His predictions were also too pessimistic as they were not verified at the time, but his general vision remains true in terms of trends, if not of exact outcome.

\subsection{Environmental philosophy and Philosophy of environment}

"Environmental philosophy is a branch of philosophy that is concerned with the natural environment and humans' place within it" [45]. It includes environmental ethics 
(cf. Sect. 6.4) and other sub-disciplines discussed further.

The expression Philosophy of environment designates the same discipline, in as far as it is still loosely structured and nascent, in some countries like France.

The Philosophy of environment is sometimes treated as a separate discipline from environmental philosophy, focusing on some particular issues and schools of thoughts, like Evolutionist Humanism, which ought to be considered more like a sect or a religion than a philosophical discipline or like a free-thought endeavor still looking for a proper philosophical framework [46]. It refers to thinkers like Jacques Monod, Richard Dawkings [47], Stephen Jay Gould, who have all written extensively for the general reader. This is somewhat similar to the theory of Gaia of James Lovelock [48] which proposes an image of the biosphere as a global, self-regulating living organism, which is best seen as an ad hoc metaphor of the mechanisms involved in a global ecological system rather than as a scientific theory.

\subsection{Environmental ethics: major concepts and schools of thought}

Environmental Ethics is the most prolix chapter of environmental philosophy. It started to be developed in the $1970 \mathrm{~s}$, as a response to the identification of the environmental issues of $5.1[49,50]$ : it is an exercise in practical philosophy to help policymakers and society stakeholders find their way around thorny issues and help solve them. Only Philosophy, among academic disciplines, has the clout to offer this kind of service.

The two central questions raised by environmental ethics are to identify: (1) what ought to be done with respect to the environment, from the standpoint of humankind and (2) why?

The second question is the most pressing one: why should "we" act, we, mankind? Why should we preserve the environment? What are the moral principles that would urge us to do so? What has an intrinsic value that we should strive to preserve it? People, human beings, humankind on the one hand, or living creatures beyond humans on the other hand or environmental systems (ecosystems) in a more general way? Several kinds of answers were proposed, from purely anthropocentric to ecocentric ones, with various shades of grey in each case. Which of these ought to be given moral priority?

Anthropocentrism in Environmental Ethics has also been called human-centeredness or human chauvinism: it states that humans are the only things that matter on Earth. It is a very old concept that can be traced to Aristotle, who maintained that "nature has made all things specifically for the sake of man" [51] and that "the value of non-human things in nature is merely instrumental', and to the Bible: "Then God said, Let Us make man in Our image, according to Our likeness; let them have dominion over the fish of the sea, over the birds of the air, and over the cattle, over all the earth and over every creeping thing that creeps on the earth" [52].
Traditional Western ethic perspectives assigned intrinsic value ${ }^{10}$ to human beings alone-and not to animals or plants or ecosystems: this is called anthropocentric in a strong sense. Therefore, in that sense, protecting the environment makes sense only if this helps protect people, for example for health reasons, because of toxic emissions, or for avoiding the dire consequences of global warming run amok. Or if intrinsic value is also assigned to non-human things, then a greater amount of intrinsic value would be assigned to human beings because "the protection or promotion of human interests or well-being at the expense of non-human things turns out to be nearly always justified" [49]: this is called weak anthropocentrism. The third law of robotics belongs to this category [53]. ${ }^{11}$

The companion to the concept of intrinsic value is that of consequential value: ${ }^{12}$ what is good may not be directly related to the action one is envisioning, but rather to the consequences of this action, which is in that case means towards getting something else: thus, "anthropocentrism often recognizes some non-intrinsic wrongness of anthropogenic environmental devastation; such destruction might damage the well-being of human beings now and in the future, since our well-being is essentially dependent on a sustainable environment" [49]. There is a strong connection between consequential value and extrinsic value [54].

Note that axiology, the subdiscipline of philosophy that studies value, is applied both to ethics and aesthetics: this may help point out that the value of nature and of the environment also somehow possess an aesthetic dimension. One may want to preserve the biosphere, not only for its usefulness in maintaining the sustainable conditions under which mankind can thrive, maybe even survive, not only for its own sake, but also for simple aesthetic reasons: the Earth indeed is a beautiful planet! Moreover, "the aesthetic appreciation of nature has the power to re-enchant human life" [49].

Some thinkers believed that there is no need to develop non-anthropocentric theories: the environment can be adequately protected by using what they call enlightened, prudential or consequential anthropocentrism. This may be an explicit stance like enlightened anthropocentrism or a

\footnotetext{
${ }^{10}$ this expression refers to the philosophical discipline of axiology, which is the study of value in ethics (consequentialist concepts: good and bad, or deontological concepts like right and wrong, which are known as thin moral concepts, while kindness, honesty, sincerity and justice are thick concepts, related to virtue ethics) or in aesthetics (beautiful and ugly).

11 The law of robotics, a playful construction of science-fiction writer Isaac Asimov, have been used to think about artificial intelligence and of how to deal with it in the future, when ethical issues are raised in this new context. The 3rd law stipulates: $A$ robot must protect its own existence as long as such protection does not conflict with the First or Second Laws.

${ }^{12}$ Consequential arguments are often used to promote normative attitude towards environmental issues. For example, there is an on-going advertising campaign, in Montpellier, France (2018) to promote glass recycling: «Il faut vous le dire comment? Bien trier le verre, c'est dans votre intérêt».
} 
cynical, hidden stance, like the latter two approaches, an indirect form of consequentialism, which has attracted vehement critical rebuttals [55].

Richard Routley (1935-1996), an Australian philosopher, picked up the American ideas and feelings related to nature and wilderness and took them a step further by stating that non-human objects have intrinsic value in his "last human" parable [56]. ${ }^{13}$

A bridge between ethics and law was launched by Christopher Stone in 1972: he proposed that trees and other natural objects should be considered as legal entities, like companies and corporations do [57]. Thus, they could be represented in their own right in the courts by groups such as NGOs.

This did not lead to an overhaul of the legal framework in the US, but it solidly focused attention on the environment.

Joel Feinberg pointed out that in order to have legal and moral standing, items had to have interests, capable of being represented in legal proceedings and moral debates [58].

This was concomitant with the emergence of political activism around the idea of animal rights.

By then, Environmental Ethics, political activism and legal debates had converged to create a lively discussion about environmental issues at all these three levels. There were deep disagreements between parties, especially at the level of political activism, between those who were in favor of reform and of working with institutions and business, the "liberal environmentalists", and those who were calling for no less than a revolution, the fundamentalists or "fundies". There was thus a distinction between shallow and deep environmental movements, which is paralleled by another distinction between weak and strong sustainability [59].

The concept of deep ecology was proposed by Arne Noess (1912-2009), a Norwegian philosopher and mountain climber. ${ }^{14}$ His intuition came from his experience in climbing summits in the Himalayas in the company of Sherpas, who revered mountains as living beings and refused to climb some of them. Næss position was to extend this reverence for mountains to other natural things in general. He saw himself as a political activist as much as a philosopher.

Næss defines the deep ecology movement in contrast to the shallow ecology movement, which is the "fight against pollution and resource depletion", an approach developed in the Western world and therefore one concerned with "the health and affluence of people in the developed countries" [60].

\footnotetext{
13 "He imagines a hypothetical situation in which the last person surviving a world catastrophe acts to ensure the elimination of all other living things and the last people set about destroying forests and ecosystems after their demise. From the human-chauvinistic (or absolutely anthropocentric) perspective, the last person would do nothing morally wrong, since his or her destructive act in question would not cause any damage to the interest and wellbeing of humans, who would by then have disappeared. Nevertheless, Routley points out that there is a moral intuition that the imagined last acts would be morally wrong".

${ }^{14} \mathrm{He}$ developed his thoughts with discussions with fellow Norwegian climbers Sigmund Kvaløy and Nils Faarlund.
}

The deep ecology movement, on the other hand, endorses "biospheric egalitarianism", the view that all living things have value in their own right, regardless of their usefulness to others - this is akin to the modern view of scientific ecology that sees ecosystems and biodiversity as the central backbone of the operation of nature, although transposed in terms of ethical value; the same concept already existed in Spinoza's metaphysics, who rejected atomistic individualism in favor of a more holistic vision of the whole biosphere, individuals being simple knots in what he calls the biospherical net. A living thing's identity is constituted by its relations to other things in the world, as seen by the ecological connections to life in general.

The deep ecologist respects the intrinsic value of natural things: for example, when walking on the mountainside, he is careful not to cause damage to plants - a behavior generally encouraged in National Parks today, without necessarily referring to Næss.

An evolution of Næss' ideas led him to assume that the human ego could identify with nature as a whole, thus enlarging one's Self (written with a capital S) beyond his body's boundaries - the theory of expanded self. This is somewhat akin to the religious belief of Zen, which professes to help the individual, through meditation, become aware of the fluxes of life of which he is a part and let them flow through him. Næss called his philosophy Ecosophy.

Næss did not elaborate on the key questions that the concept of intrinsic value attributed to any natural object, living things like animals and plants, but also rivers, mountains, bacteria or viruses raised in the framework of Environmental Ethics - in particular as far as defining their interests was concerned. The translation of deep ecology to the political and legal contexts was also left to political activists or to other experts (see Sect. 7).

In the US, deep ecology has been considered as close to the land ethics of Leopold, a rapprochement to which Næss objected as he found it too totalitarian.

Næss' deep ecology has been criticized by feminist philosophers, because it represents a form of human colonialism, akin to many male-oriented attitudes towards women. Third world critics have called it elitist, in as far as it aims to preserve the environment for well-off people in rich countries.

Note also that, mutatis mutandis, deep ecology reminds of Bruno Latour's Actor Network Theory (ANT), a sociological and anthropological theoretical framework which posits that networks of relationships between living and non-living things explain social interactions [61].

The further evolutions of concepts in Environmental Ethics and Environmental Philosophy are reported in the next section, under the heading of "more radical approaches". Indeed, what was reported in the present section can be considered as mainstream Environmental Ethics.

\subsection{More radical approaches: ecofeminism, ecocriticism and social ecology}

Feminist philosophers, most of them women, introduced a new vision of the connection of science, technology, industry and environmental issues with broad social 
mechanisms that go beyond the analyses of contemporary social science and imply discrimination and exploitation against women. The concept of human-centrism or anthropocentrism becomes androcentrism in the vocabulary of feminist philosophers.

Carolyn Merchant's classical book, The death of Nature [62], explains how the Earth (the geosphere) can be viewed as a maternal matrix which grows metal ores and minerals in its womb and delivers them to the surface to be later transformed into metals or other materials, for the smooth functioning of human society.

More crudely and, historically much earlier, Francis Bacon (1561-1626) explained that the Earth is dug with holes (the mines), which act as vaginas that are raped by society and this lets ores emerge outside of the ground to eventually produce metals, etc. $[63,64]$ : the process is violent but is the price to pay for advancing science and technology. It is based on the methods of inquisition and torture of witches, he implied. Modern critics have traced the connection between technology and environmental degradation to Bacon $[65,66]$, giving him probably too much responsibility for events that took place centuries beyond his time.

"By the mid 1970s, feminist writers had raised the issue of whether patriarchal modes of thinking encouraged not only widespread inferiorizing and colonizing of women, but also of people of color, animals and nature. Sheila Collins [67] (1974), for instance, argued that maledominated culture or patriarchy is supported by four interlocking pillars: sexism, racism, class exploitation, and ecological destruction" [quoted from 49]. Feminism puts stock in the concepts of domination and power, which is also at the center of a strong theoretical debate in anthropology.

The expression ecofeminism was invented by French writer and activist Françoise d'Eaubonne (1920-2005) ${ }^{15} \mathrm{It}$ is now commonly used to refer to this school of thought.

The debate between disenchantment of nature and new animism, initiated by the Frankfurt neo-Marxist School of Max Horkheimer and Theodore Adorno [68], is at the core of a theoretical discussion that took place in the 1970s. Initially, they objected to Marxism, which is based on a positivist attitude towards nature, driven by science, the pursuit of progress, of power and of technological control: they saw Marxism as anthropocentric and as adding an extra layer of alienation to human nature and as disenchanting nature, i.e. freezing it in a deterministic rationality and killing it as in a still life painting. They were looking for a new dialectical synthesis between Romanticism and Enlightenment. They proposed to achieve this objective by looking for freedom, creativity and spontaneity in the values of the aesthetic, moral, sensuous and expressive aspects of human life in an approach called new animism, coming just short of the animist visions of the

\footnotetext{
${ }^{15}$ Besides ecofeminism, she coined the word phallocrat. She was one of the founders of the Mouvement de Libération des Femmes (MLF) in France, where she was in charge of the group "Ecology and feminism".
}

First people. This is where the theory comes close to aesthetics: art, like nature, offers an excess of representation that reaches beyond its materiality and its exchange value.

Ecocriticism is a critical approach, proposed by Adorno on the basis of literary critical theory, which looks at the production of writers from the standpoint of environmental issues, based on techniques of deconstruction, psychoanalysis and radical social theory. This, incidentally, leads to the deconstruction of the notion of nature and to the paradoxical slogan "down with nature!".

Social ecology, an approach proposed by Murray Bookchin [69], an anarchist theoretician, plans to revisit the coupled concepts of nature and nurture or nature and culture, by distinguishing between first nature and second nature. Environmentalism, according to him, is a social movement and the issues it confronts are social problems. Bookchin also thinks that nature is an aesthetic marvel, in which humankind has a special role to play, not to control, harness or violate it, but to help it maintain its complexity and diversity, while curbing pollution.

Environment and economics have entertained close connections, especially in methods designed by economists to internalize the externality that the environment usually is considered to be, in their own (neoclassical) views, such as cost-benefit analysis, the willingness-to-pay (WTP) criterion or the concept of nature capital. Some writers see the use of these concepts "as instrumentalizing natural things which are in essence wild and free" [49]. Famous attempts have been made at pricing the cost climate change, in terms of action or inaction [70], and the value of Biodiversity [71]. However, the efforts come from the side of economists and thus introduces a methodological bias, similar, mutatis mutandis, to those pointed out by ecofeminism or social ecology. To overcome these limitations, Mark Sagoff has introduced the distinction between people as consumers and people as citizens in order to avoid the strong anthropocentrist views that come along with standard economic approaches -i.e. the economics school of thought distinct from environmental economics [72]. Cost benefit analysis, he says, cannot tell us the value of nature and therefore approaches like compensations for GHG emissions or for loss of biodiversity are suspect or miss the point: not everything, especially as far as the environment is concerned, is economic in nature!

To accompany the new understanding of ecology that nature and life are embedded in complex ecosystems, which connect together to form biomes and eventually the biosphere, as well as activism like that related to animal liberation, Environmental Ethics has explored new ways of acknowledging the intrinsic value of living and non-living natural things. This means reexamining consequentialist ethical theories, deontological ones and virtues ethics (cf. footnote ${ }^{10}$ and Sect. 6.5).

Consequentialist ethical theories consider good and bad to be more fundamental moral notions than right and wrong and maintain that whether an action is right or wrong is determined by whether its consequences are good or bad. 
For utilitarians, a family of consequentialists, "Right actions are those that would produce the greatest balance of pleasure over pain" [49]. Peter Singer [73], "has argued that the interests of all the sentient beings ${ }^{16}$ [thus humans and non-humans alikel affected by an action should be taken equally into consideration in assessing the action" [49]. Giving more weight to human beings is a kind of speciesism, an attitude as arbitrary as sexism or racism. He considered the animal liberation movement as comparable to the liberation movements of women and people of color. Singer thus attributed intrinsic value to the experience of pleasure and pain, thus not directly to beings in general but more specifically to sentient beings. Thus, plants species or landscapes or rivers do not hold any intrinsic value according to this school of thought and therefore it is unclear if a utilitarian ethic can also be an environmental ethic.

Deontological ethical theories maintain that the rightness or wrongness of an action is unrelated to its consequences, good or bad. The intention is essential, not simply the outcome. Tom Regan [74], also an animal-rights advocate, posits that animals have rights, which should not be violated by practices like hunting or laboratory experiments on animals, whatever good may be expected of them. He came up with a criterion for defining a being which deserves a respectful treatment: it called it a "subject-of-life", i.e. it should have perceptions, expectations, longings, memory, a sense of the future and some kind of psychological identity over time. A weaker version of this criterion, called biocentrism, is concerned with "teleological-centers-of-life", i.e. beings endowed with a well-being of their own deserve being credited with intrinsic value.

More recently, a solution to the paradoxical tension between the two approaches was proposed, whereby it is assumed that there are two complementary conceptions of intrinsic values, the consequentialist one which supports the state of affairs and the deontological one which respects entities for themselves.

All of the above approaches are individualistic, i.e. refer to individual beings. But what about ecological wholes, ecosystems, that need to be preserved? The statement of Leopold (land ethics): "a thing is right when it tends to preserve the integrity, stability, and beauty of the biotic community. It is wrong when it tends otherwise", was revived by J. Baird Callicott [75]. "In this theory, the earth's biotic community per se is the sole locus of intrinsic value, whereas the value of its individual members is merely instrumental and dependent on their contribution to the "integrity, stability, and beauty" of the larger community" [49]. This position was dissected and accusations of ecofascism were addressed to Callicott: he eventually changed his position and acknowledged that both ecosystems and individual species have intrinsic value. The controversy is not resolved yet.

Virtue ethics considers the quality of actions, thus thick concepts like kindness, honesty, sincerity and justice, rather than the thin concepts involved in consequential and

\footnotetext{
$\overline{16}$ i.e. beings who are capable of experiencing pleasure or pain.
}

deontological ethics and it questions the moral reasons for acting one way or another. As the central issue of virtue ethics is "human flourishing", it would seem to be an anthropocentric approach. But since love and appreciation of nature is part of human flourishing, the approach may be seen as ecocentric as well.

Note, finally, that the built environment can be included in the framework of Environmental Ethics, with some minor adjustments: after all, a city is an ecosystem of its own with a specific kind of local biodiversity. A single ethical theory would include both built and natural environments, thus erasing the traditional distinction and higher value of wilderness against the artifactual, questioning the intrinsic value of non-human things and steering away from what some have called "biophilia". Robert King [76,77], Andrew Light [78], Clare Palmer [79] and Warwick Fox [80] are working in this direction.

The review proposed in Sections 6.5 and 6.6, gives an idea of the diversity of approaches and standpoints exposed in the Environmental Ethics literature, which has exploded since the $1970 \mathrm{~s}$. There is a pragmatic dimension in this field like in other scientific domains, whereby authors explore new directions of thoughts, with the traditional tools of philosophical discourse. There are also clearly schools of thoughts, which differ and do not claim a coherent approach for the whole domain, are ripe with controversies and entertain harsh discussions. A practically-minded person, focused on making use of the production of the field for example for political action, is left with many open questions and options (cf. Sect. 6.7).

Among pure philosophers, Michel Serres (born 1930) holds a special place, given his background as a philosopher of science and his gift as a writer [81]. He explained in 1990 in the Natural Contract [36] that the old Social Contract of Jean-Jacques Rousseau (cf. Sect. 6.1) is no longer sufficient today to account for the complexity of the relationship between society and nature: a contract of mankind with nature should be put in place to complement the contract of mankind with itself; this would mean giving Nature both intrinsic value in the sense of ethics and legal entity in the sense of law (cf. Sect. 7), complete with a Universal Declaration of the Rights of Nature, similar to the Universal Declaration of Human Rights, and the possibility for Nature to fight for its rights in court. Lawyers have not yet found ways to implement this approach, except in the very few countries, where non-western culture has been given the floor (cf. Sect. 7).

\subsection{How do various institutions fare regarding Environmental Ethics?}

International Institutions acknowledge the burden of the threats posed by environmental issues, especially the most pressing ones such as climate change or the drop in biodiversity, and they have developed methods and programs to deal with them. This is true of the United Nations, of the European Union but also of the Catholic Church. At a more local level, most National governments have developed a framework for their sustainability commitments (cf. Sect. 7) and business has joined in, helped or corralled by NGOs specializing on environmental 
issues. Moreover, political activists have organized in Green Political Parties which push a green agenda within a doctrine of more general political and social objectives, often leaning to the left.

The questions raised in this section are of a different nature from those that ethics deals with, since the matter is about social and political action. It is therefore necessary to produce original developments in the fields of philosophy and of social sciences, which will be reviewed in the present section.

The quasi-universal answer to environmental issues at the level of action, political or otherwise, is Sustainable Development or Sustainability (cf. Sect. 5.2). The concept was introduced in the Brundtland report to the UN published in 1987 [82] but commissioned in 1983, i.e. at a time when Environmental Ethics was still a very young discipline. Sustainable development is defined as development that meets the needs of the present without compromising those of future generations. The focus is on present needs, with the poor in the world as the main target and the fact that economic and social conditions put limitations on the ability to meet present and future needs; as pointed out earlier, it also a kind of contract of the present with the future, in this case future generations. As explained earlier (cf. Sect. 5.2) and elsewhere [59], Sustainable Development is not an objective statement of what can actually be achieved in the future but rather an inspirational goal, moral and ethical in nature, on which political institutions and other societal stakeholders should focus.

There are clear philosophical, political and economic precursors to the Brundtland concept of sustainability, for example John Stuart Mill [83], who acknowledged that beyond a development stage came a stationary stage, because "the increase of wealth is not boundless". Thomas Malthus was also a precursor, although a more pessimistic one. And the Club of Rome led by Dennis Meadows reaffirmed these worries [84], in line with the publications of John Ehrlich [43].

When the concept of sustainable development was first introduced in the Brundtland report, it was clearly anthropocentric. Non-human beings or things did not belong in the formulation for their own sake but rather as a means to guarantee the present and the future of human societies, a consequential argument. ${ }^{17}$ The recent evolution of the concept of Sustainable Development hardly moved it beyond that point. However, all environmental burdens and issues were included in the definition of Sustainability, as soon as they were identified, such as, for example, biodiversity, water scarcity or climate change: "objective" scientific facts were more readily acknowledged than new philosophical approaches.

\footnotetext{
${ }^{17}$ Forests, rivers, oceans and other ecosystems, including the natural species living in them, constitute a stock of ecological capital from which all kinds of goods and services flow (concept of sustainable yield). This economy-based concept is resisted by Strong Sustainability theorists: in their views, natural or ecological capital cannot substitute for ordinary economic capital and vice versa.
}

The Brundtland report pays less attention to limits than Mill, Malthus or the Club of Rome. The focus is more on fairness for the poor of the world and poor countries and on the challenges that the goals of equity and inclusion raise.

Garrett Hardin stated that "the population problem has no technical solution; it requires a fundamental extension in morality" [85] in a famous article dedicated to what he called the tragedy of the commons, i.e. common resources ${ }^{18}$, because they are the subject of degradation and extinction: indeed, he says, society is driven by self-interest and even by corruption, which have no room for commons. Thus, development goals, like the UN's sustainability goals (cf. Fig. 1), are not sufficient to provoke the conservation of nature; there are also moral obligations, at individual and collective levels, to which one should abide.

Another important paper by Stephen Gardiner [86] analyzed the case of climate change and tried to diagnose why political action to put the phenomenon under control has been weak beyond the declarations of international treaties like the Paris Agreement of 2015. He explained that the matter of climate change is first of all a moral matter, which raises a number of ethical questions which are so complex and numerous that they behave like a storm, a moral storm, indeed a perfect moral storm. And, he went on to say, this makes us vulnerable to moral corruption. This is due to the multiplicity of agents and players and to the egoistical drive for self- interest pointed out by Hardin.

An example of moral corruption is proposed by Bruno Latour [87], who posits that the "super-rich" have actually fully analyzed the risks of climate change, for example a catastrophic increase in temperature of more than $6^{\circ} \mathrm{C}$, but they believe they can survive it in isolation as a small community, contrary to the rest of the population, which, anyway, they consider as responsible for the present disorders $^{19}$ [88].

A number of philosophical developments are still necessary to help policymakers make decisions about environmental issues. These are the principle of responsibility, the precautionary principle and lesser rules like the polluters-pays rule or the waste hierarchy.

Hans Jonas (1903-1993) has dealt, rather courageously, with the moral question of whether future generations have rights in his 1979 book, the Imperative of Responsibility $^{20}[89]$. His argument is that the question has no answer in the framework of classical ethics, with focuses on

\footnotetext{
18 These are externalities, in the language of economists.

19 This is no less than an attempt at solving the matter of Climate Change by bringing back population to pre-industrial levels, a genocidal proposal of massive proportion. Note that some ethicists have been playing with such ideas, like Rolston (1996) for instance, who claimed that (some) humans are a kind of planetary "cancer". He maintained that while "feeding people always seems humane... when we face up to what is really going on, by just feeding people, without attention to the larger social results, we could be feeding a kind of cancer."

${ }^{20}$ The title has been chosen as an answer to the book of Ernst Bloch, the Principle of Hope, which supports the Marxist view of an utopian future in which progress can continue indefinitely, if properly stirred at a political level. A position in 1954, when the book was published, which was already passé.
} 
the individual, and that a new principle has to be added, that of "our" responsibility for mankind in general, the planet as a whole, non-human beings or things and future generations which are not born yet and thus would "normally" not be able to claim any rights - thus not a responsibility for our own actions, but one based on a benevolent view of mankind and its fate on Earth. This, he says, is a matter of survival, as the fact that the connection between mankind and nature has been inverted in recent times calls on new rules and new approaches ${ }^{21}$. The book, which addressed a more general public than the Environmental Ethics cognoscenti, was received with hostility by some, in France, for example, but politicians saw it as the opening they were looking for to base their decision-making related to environmental issues and more generally to technology. Jonas gave them an open-ended program based on the concept of respect for others.

The precautionary principle is seen as derived from the ideas of Jonas, but at the level of the law rather than of ethics. It is a translation of the German expression Vorsorgeprinzip. It was introduced at the Rio Earth Summit in 1992, i.e. contemporaneously to the Brundtland report, 20 years after Jonas' book. The idea is that legislation should take discretionary steps to bar chemicals (and materials) or technologies that may cause harm to the environment or to people (this includes food) to alleviate risks of a serious and irreversible nature, even if science has not yet provided definite proofs of harm. ${ }^{22}$ The precautionary principle is now strongly anchored in EU regulations and hence in the legislation of Member States. Its use, however, is sometimes overextended, when politicians hesitate on what course of action to take, or the principle is not used, for example when industrial lobbies convince the authorities that the case is not clear enough to make a decision, like in the case of pesticides (neonicotinoids), herbicides (glyphosate) and endocrine disruptors. Note that Jonas, who is often seen as a precursor of the precautionary principle, called it an example of the heuristic of fear [89].

The polluter-pays principle is an internalization of pollution costs, in the sense of economics, in a logic of reparation and prevention. It offers a solution to the resolution of pollution issues, which law and courts have been relying upon. It does not necessarily imply a direct responsibility for the pollution event in the sense of traditional law, but rather in the sense of Jonas. Direct responsibility is often the case, though, but the principle is being applied to situations which are more ambiguous, like Greenhouse Gas (GHG) emissions, which do come out of a smokestack or of an exhaust pipe (the polluters), but may be considered as the responsibility of the whole value chain

\footnotetext{
«Agis de façon à ce que les effets de ton action soient compatibles avec la permanence d'une vie authentiquement humaine sur terre».

22 "In order to protect the environment, the precautionary approach shall be widely applied by States according to their capabilities. Where there are threats of serious or irreversible damage, lack of full scientific certainty shall not be used as a reason for postponing cost-effective measures to prevent environmental degradation" (UN declaration).
}

which led to these emissions and, why not, mostly of the energy resource producers [90].

The waste hierarchy is a detailed rule used to prioritize between ways of disposing of anthropogenic waste: it establishes a petty order, where avoidance stands at the highest ethical level and landfilling at the lowest. It thus points out to the "best" solution that ought to be selected in an ecodesign approach but also opens the way to trade-offs among various solutions, which raises ethical issues.

One important philosopher and sociologist, Ulrich Beck (1944-2015), rejected the separation of disciplines implied in the previous analyses and explained that the present intimate connection between nature, the biosphere and mankind or the anthroposphere is not simply a historical development that describes a collision between separate histories but rather the result of the historical evolution of society itself. Society has been creating risks which it has to face and deal with, not as an exogeneous phenomenon but rather as an endogenous one. Politics meets Ecology in his Theory of Risk book, at an ambitious and fascinating level [91].

The Catholic Church is also an important institution, especially since western culture and the science, technology and attitudes to the environment that it vehiculates are deeply influenced by Judeo-Christian tradition. The quotes from the Bible mentioned in Section 6.5 have long been tempered, for example by the views of Francis of Assisi (1181-1226). In 1997, Pope John-Paul II declared [92]: "in the name of an idea inspired by egocentrism and biocentrism it is being proposed that the ontological and axiological difference between men and other living beings be eliminated, since the biosphere is considered a biotic unity of undifferentiated value ${ }^{23}$." More recently, the Holy Sea published the Encyclical Letter Laudato Si' [93], which explicitly adopts the concept of Sustainability: nature should be preserved and the role of human beings should take proper care of the Earth, "to till and keep it", rather than brutally "take dominion" of it

Business (Corporate Sustainability Reports, Corporate Social Responsibility) has also embarked into some versions of Sustainability, as analyzed in [59]. They do not necessarily conform with the most advanced versions of environmental ethics but they demonstrate a willingness to deal with the responsibility, Jonas' style, that they feel towards the environment. CSR covers a wide range of styles, from genuine pro-active attitudes to coarse greenwashing.

\footnotetext{
${ }^{23}$ If this statement looks like an opening towards bio- or ecocentrism, the address goes on to say: "If humanity today succeeds in combining the new scientific capacities with a strong ethical dimension, it will certainly be able to promote the environment as a home and a resource for man and for all men, and will be able to eliminate the causes of pollution and to guarantee adequate conditions of hygiene and health for small groups as well as for vast human settlements"-which reverses back to an anthropocentric position, mitigated by the religious view that "it is the relationship man has with God that determines his relationship with his fellows and with his environment".
} 
The case of environmental NGOs is even more diverse, especially since some of them, like Greenpeace, tend to be on the activist side of environmentalism.

\section{Environmental laws, codes and regulations}

Environmental law is both hard and soft law and relies as much on science, the science of Life and scientific Ecology, as it does on traditional law approaches. As such, it is fairly fluent in what we have called environmental issues (EI), including the most recent ones of them.

Environmental law is broad and ambitious, calling on solidarity and reconciliation-between the partisans of growths and those of ungrowth-as a way to deal with the EI [94]:

- it has adopted the concept of Sustainable Development and is therefore universalist in time and space, thus recognizing that EI do not stop at national borders and that they propagate into the future; it is fertilizing all the fields of law, playing the role of a guiding principle, and environmental law is now included in the constitutions of many countries;

- it is federating law and science, life and social sciences especially;

- it is a law of Life;

- it makes it necessary for the lawmaker and the lawyer to think in a different way, i.e. start from first moral principle in a hermeneutics way and then move on to specify objective targets to deal with focused practical issues (e.g. emission limit on dioxins);

- Environmental Law is a systemic law which ambitions to deal with economics, politics and the connection that both have to entertain with nature and life "in a holistic approach of milieus, cycles and natural equilibria, always under the threat of entropy but which base the elements of their renaissance in their decomposition" [94];

- it takes stock of the fact that public opinion is aware that progress brings threats for the survival of species and for human health;

- it is a law of citizen commitment and of duties to carry out as much as of rights to claim;

- Environmental Law should solve the apparent contradiction between legal certainty and uncertainties related to environmental or health threats, and this is where the precautionary principle steps in.

The Stockholm declaration of 1972 was the first global international statement on the connection between mankind and nature. It said, in its first principles: "Man has the fundamental right to freedom, equality and adequate conditions of life, in an environment of a quality that permits a life of dignity and well-being, and he bears a solemn responsibility to protect and improve the environment for present and future generations" [95] and: "the natural resources of the earth, including the air, water, land, flora and fauna and especially representative samples of natural ecosystems, must be safeguarded for the benefit of present and future generations through careful planning or management, as appropriate" [96]. The Rio declaration followed up 20 years later, which modernizes the language and broadens the scope of "environmental protection" [97].
Thus, Law has picked up EI and developed a framework to deal with them, in resonance with its disciplinary methods and culture, roughly at the same time as the other stakeholders in the areas, i.e. the second half of the 20th century. Law was not particularly late, if one overlooks the delays that some countries introduced in its implementation, but it developed on its own, not necessarily looking for conceptual support from other fields.

Reference to Environmental Ethics, however, is not common in the Law literature and it would seem like Environmental Law is stuck in the earlier debates on the anthropocentric role of man to protect the environment and on the reasons for protecting it, in most parts of the world-as the constant reference to the Stockholm declaration would seem to attest. This would be a reductionist view, however, as environmental law seems to have been built directly on science, or so it claims [94], and to have short-circuited the ethics debate which proceeded also at its own pace: "les partisans de l'anthropocentrisme et ceux de l'écocentrisme en sortent affaiblis puisqu'il est difficile de nier les droits de la nature et les droits de l'homme 24 " [94].

Environmental Law has been organized at national and international levels [98] since the end of the second world war, with different accomplishments in different parts of the world. The International Convention for the Regulation of Whaling published on 2 December 1946 stands as one of its first impersonation.

Environmental Law is being implemented at supranational levels, the Federal government in the US and the EU in Europe and of course also at national levels. The UN and various other international agencies are in charge of some of the major environmental issues of world dimension, like Climate Change (the UNFCC), biodiversity, stratospheric ozone, acid rain, etc. (cf. [99]). Environmental Law is organized in many countries in an Environmental Code $[100,101]$ and key principles are included today in many constitutions.

Lesser issues, such as more local pollution issues, are handled at national or supra-regional levels.

Recent developments [18] have given legal status to environmental things like a river or a lake in India and New Zealand. In Ecuador, since 2008, Nature has been given "intrinsic" rights: Mother Earth, Pachamama, has thus become a legal entity.

What is happening, is that Environmental Ethics, a euro- or western-centric discipline, has been discovering or reinventing concepts which are common in non-Western traditions, either philosophical or religious. Present, postmodern thinking is thus reverting back to ancestral natural philosophy!

\footnotetext{
${ }^{24}$ Lawyers define the two concepts slightly differently from ethicists: anthropocentrism states that only humans have rights, whereas ecocentrism attributes rights to nature (understood as what is not human or has not been touched by humans) as well. Having rights does not mean being a legal entity however, another level of subtlety in law concepts.
} 


\section{Measuring the social and environmental values of objects, technologies and services}

In the burgeoning struggle to develop new ways of dealing with modernity and post-modernity, the methods that were devised to bring numbers and measurements into the fray hold a special place that calls for a particular discussion in this article.

Historically, the first such method is Life-Cycle Assessment, LCA, which was also invented in the 1970s and is born of the marriage of physics (mass and energy balances) and accounting (financial balances) [102]. The point was to devise practical ways to bring environmental issues on board within the culture of industry, therefore to use the languages of business managers and engineers. The focus was clearly on emissions and on their environmental impact, pollution. The approach was pragmatic, based on the understanding that environmental issues of various importance were being acknowledged and that they called for action from the side of industry, which was seen at the time as the major source of the problems.

LCA developed briskly and quickly, adopting the language and worldview of sustainable development, while taking on board environmental issues, health issues and a category of social issues related to labor law [103]. In parallel, the field attracted the attention of that part of the legal world that deals with standards and this gave birth to a series of ISO standard. ${ }^{25}$ It is interesting that LCA, for example as it is taught in higher education institutions, is defined and explained from the standpoint of standards, an interesting case of metonymy!

LCA does not connect clearly to the concepts defined by Environmental Ethics, as the fields grew in parallel and were not necessarily aware of each other, an exacerbated case of silo behavior. Some researchers, though, have attempted to bridge the gap [104].

A post-mortem analysis would conclude that the field started as an anthropocentric endeavor, with researchers in LCA scrambling to bring fixes to environmental issues. The focus on the environment, rather than on the businesseconomic and the social dimensions, attracted LCA towards the scientific ecology side of the debate, under the influence of the academics who started to take charge of the field. ${ }^{26}$ This probably explains why the developments stemming from universities have been hard science-centered. ${ }^{27}$ On the whole, however, LCA is an applied science at best, probably rather a technology.

\footnotetext{
25 The ISO $14040 / 14044$ series.

26 thus based on a lopsided understanding of sustainability.

${ }^{27}$ This includes the developments related to toxicology and ecotoxicology and, more generally, the tendency to transform LCA into a "theory of everything", somewhat similar to what high-energy physics has been attempting to do, although with widely different tools and approaches.
}

More recently (1990s), the field arrived at the concept of areas of protection [105], which has been the subject of many arguments and discussions but aims at unifying a multitude of indicators ${ }^{28}$ on the basis of the classical dichotomy between nature and mankind, i.e. between the technosphere or the anthroposphere and the biosphere and the geosphere. Note that conceptual innovation was meant to solve a practical hurdle, that of simplifying overly complex LCA analyses for the benefit of decision makers. The concept of intrinsic value seems irrelevant in this particular context and the approach, although taking on board a holistic view of the physical world, does not acknowledge the attempts of environmental ethics to propose a different worldview that might also benefit the LCA community. Other methodologies were invented to alleviate the downsides of LCA, namely Material Flow Analysis (MFA) and other approaches like Sustainable Technology Assessment (STA). Where LCA looked at the world from a microstandpoint and then added things up to build a more macrovision, MFA looks at flows of matter or energy at a large scale and therefore acknowledges that large-scale systems are at the core of things and that relationships, connections, networks are key to a proper vision of how the world operates. This introduces a kind of thermodynamics of ecology, with concepts like entropy available to capture some features of the system, which would otherwise remain obscure. This also connects with the concepts of Deep Ecology and of Actor Network Theory (ANT). The foreword of this article (Sect. 1) already touched on these matters.

Both methods have to deal with the matter of defining the system in which they operate (the functional unit of LCA, for example): this introduces a bias in the way they describe the world. I would tend to think that both LCA and MFA are intrinsically anthropocentric, although they could probably be steered in an opposite direction, if more moral weight was given to "nature"29.

\section{Conclusions}

The connection of mankind, i.e. society or the anthroposphere, with nature and the environment, also called the biosphere or the ecosphere, has been taken for granted since the end of the 20th century in the general public and also in scientific and industrial circles. The buzz word is Sustainability or Sustainable Development. Everyone seems to have adopted it as an ethical objective, from the side of business, environmental NGOs, political institutions and actually almost any stakeholder, at regional, national, supra-regional or world level. This is particular true in the activities related to materials.

This is a fairly new development, dating back to the end of the 20th century, when pollution and other serious environmental issues have attracted attention and called for action. When alarms were sounded, the science of the environment, ecology, developed and brought some

\footnotetext{
$\overline{28}$ The initial areas of protection were: human health, man-made environment, natural environment, and natural resources.

${ }^{29}$ Industrial Ecology, which started (on the right foot) as the metaphor of the anthroposphere based on the model of the biosphere, ended up actually as an anthropomorphic discipline.
} 
scientific insight into the complexity of the phenomena involved. Political activism also grew, driven by some social NGOs and by green political parties in the US and in Europe. Law pitched in with its own sensitivity and developed a framework of legislation and regulation, which is now tightly embedded in the life of the economy, industry and business, even if, in a country like the United States, this is presently being unraveled by the EPA commissioner (2017-2018).

This has created a rather deafening background noise, which has been difficult to understand and to analyze. Thus, the question arose of whether there was any coherence among these different approaches and, if the answer was yes, how could it be highlighted?

When in doubt at an intellectual level, then ethics and philosophy may bring some useful insight.

After taking stock of the general public's understanding of the status of nature and of society and identifying what is called environmental issues today, ripe with deep uncertainties concerning the future of society and of nature itself, the article has reviewed what philosophers said about the matter. ${ }^{30}$ Initially, Nature left the realm of philosophy to enter that of science, when the two disciplines separated at the end of the Middle Ages in Europe. But as soon as Nature ceased to be a tabernacle in which mankind could safely live, i.e. in the 20th century, as a consequence of the scientific and industrial revolutions and of subsequent population growth, Philosophy lived up to its responsibilities and started to develop the field of Environmental Ethics, at the same time as the other stakeholders, scientists, lawyers, economic players, civil society institutions, policymakers and politicians or technologists measuring the social and environmental value of human activities were moving forward. Philosophy started from its own culture and intellectual concepts to develop a rich and fairly practically-minded body of work. They can be briefly summarized by the concept of intrinsic value, which can then be declined into anthropocentrism, biocentrism and ecocentrism. Not all approaches have converged yet at a theoretical level, although they are not so far apart at a practical level: law is still deeply and mostly anthropocentric while ecology, the science, is definitely ecocentric; environmental ethics is split among a variety of schools of thought, which are evolving, somewhat like nature is!

These considerations should help scientists and engineers, foremost of which those of the world of materials, become more environmentally aware in performing their missions and their duties, which are so deeply related to nature at so many different levels.

To tackle the challenges of environmental issues as they are posed today and to avoid catastrophes, it might be necessary in the future for all social players and for people of the world of materials to follow the steps of environmental ethics and to move up from anthropocentrism to the broader vision of ecocentrism.

The standpoints we have been representing here are mainly related to Western culture, which has a strong Judeo-Christian basis related to the Bible as a philosophical and conceptual background. Like most Social Sciences, they have therefore a definite ethnocentric bias. As the author has learned, teaching this kind of views in China for example, as part of a course on "sustainable materials science", - or in other parts of the world like Africa with different cultural and philosophical traditions- may present a challenge to the "professor" [106].

Acknowledgements. The author would like to acknowledge a few people, who helped him navigate through the intricacies of the environmental ethics field and to ground the connection with materials, especially the reasons why such a field should not be seen as outlandish by materials people as it is a process in which they are already engaged: Ariana Fuga, who spoke for materials scientists, Andrea Declich, who has been guiding me through the connections between materials and SSH, Karen Grandstrand [107], who taught me about ethics, Patrick Criqui, an economist deeply fascinated by climate issues, and Kathie Birat, who has been helping a hard scientist become minimally articulate in $\mathrm{SSH} . .$. on a daily basis.

\footnotetext{
${ }^{30}$ One common buzz word in the general public is that the planet is in danger and that we ought to save it. However, the present environmental predicaments seem to put society in danger, rather than the planet itself. In the geological past, more serious changes in environmental conditions have taken place and the planet has survived, due to the robustness of the mechanisms on which life is based and which we call evolution. However, we are all anthropocentrists and we would probably wish for mankind to survive without gambling our future by playing the dice of evolution!
} 


\section{Appendix A: Environmental words in various languages}

\begin{tabular}{|c|c|c|c|c|c|}
\hline English & French & German & Spanish & Chinese & Japanese \\
\hline nature & nature & Natur & naturaleza & 性质 (Xing) & 自然 \\
\hline environment & environnement & Umwelt & ambiente & 环境 (Huánjìng) & 環境 \\
\hline ecology & écologie & Ökologie & ecología & 生态 (Shengtài) & 生態学 \\
\hline philosophy & philosophie & Philosophie & filosofía & 哲学 (Zhéxué) & 哲学 \\
\hline ethics & éthique & Ethik & ética & 道德 (Dàodé) & 倫理 \\
\hline $\begin{array}{l}\text { precautionary } \\
\text { principle }\end{array}$ & principe de précaution & $\begin{array}{l}\text { Vorsorge } \\
\text { prinzip }\end{array}$ & $\begin{array}{l}\text { principio de } \\
\text { precaución }\end{array}$ & $\begin{array}{l}\text { 预防原则 } \\
\text { (Yúfáng yuánzé) }\end{array}$ & 予防原則 \\
\hline $\begin{array}{l}\text { polluter-pays- } \\
\text { principle }\end{array}$ & $\begin{array}{l}\text { principe pollueur- } \\
\text { payeur }\end{array}$ & $\begin{array}{l}\text { Verursacher } \\
\text { prinzip }\end{array}$ & $\begin{array}{l}\text { el que contamina } \\
\text { paga principio }\end{array}$ & $\begin{array}{l}\text { 污染者付费原则 } \\
\text { (Wūrăn zhě } \\
\text { fùfèi yuánzé) }\end{array}$ & 污染者は原則を支払う \\
\hline $\begin{array}{l}\text { principle of } \\
\text { responsibility }\end{array}$ & $\begin{array}{l}\text { principe } \\
\text { de responsabilité }\end{array}$ & $\begin{array}{l}\text { Prinzip der } \\
\text { verantwortung }\end{array}$ & $\begin{array}{l}\text { principio de } \\
\text { responsabilidad }\end{array}$ & $\begin{array}{l}\text { 责任原则 } \\
\text { (Zérèn yuánzé) }\end{array}$ & 責任の原則 \\
\hline
\end{tabular}

\section{References}

1. H. Rolston, A new environmental ethics: The next millenium for life on earth, Routledge, London, 2012

2. B. Latour, Nous n'avons jamais été modernes, Essai d'anthropologie symétrique, La Découverte, Paris, 1991

3. J.-P. Birat, Product innovations of key economic importance for the steel industry, Metall. Res. Technol. 115, 420 (2018)

4. V. Colla, A. Schroeder, A. Buzzelli, D. Abbà, A. Faes, L. Romaniello, Introduction of symbiotic human-robot-cooperation in the steel sector: an example of social innovation, Matériaux \& Techniques 105(5/6), 504 (2017)

5. Matériaux et société/Social value of materials (SAM-8), Matériaux \& Techniques 102(5), (2014)

6. Social Value of Materials SAM-9, Matériaux \& Techniques 104(1), (2016)

7. Society and Materials (SAM10), Matériaux \& Techniques 104(6-7), (2016)

8. Society and Materials (SAM-11), special issue of Matériaux \& Techniques 105(5/6), (2017), 13 papers published in these issue

9. Society and Materials (SAM-12), special issue of Matériaux \& Techniques 106(5/6), (2018), 11 papers published in these issue

10. J.-P. Birat, Materials, environment and society, Sustain. Mater. Sci. 1/2, to be published by EDP Science, 2019

11. A. Declich, Society and Materials: an interpretation of the subject in the light of sociology and gender, Matériaux \& Techniques 105(5/6), 513 (2017)

12. J.-P. Birat, Scientific research takes place in silos - Society \& Materials - Selection of papers from the SAM- 8 conference, Matériaux \& Techniques 102, 501 (2014)

13. J.-P. Birat, Life-Cycle Assessment-Resource efficiency and recycling, Future Circular Materials Conference 2014, Stockholm, Sweden, 23-24 September 2014

14. J-P. Birat, Society and Materials: how it all started, a few million years ago, Matériaux \& Techniques, 104(6/7), 605 (2016)

15. L. d'Andrea, A. Declich, F. Feudo, Hidden societal implications of materials, Updating the awareness on what is at stake, Matériaux \& Techniques 102, 504 (2014)
16. L. d'Andrea, A. Declich, Materials, technology and society: contributions from a sociological perspective, Matériaux \& Techniques 102, 507 (2014)

17. Jean-Baptiste Poquelin dit Molière, Le bourgeois gentilhomme, 14 octobre 1670

18. La Croix, 16 mars 2017, Available from https://www.lacroix.com/Sciences/Environnement/En-Nouvelle-Zelandefleuve-reconnu-comme-entite-vivante-2017-03-161200832407

19. A. Debourdeau, Les grands textes fondateurs de l'écologie, Champs ${ }^{\text {classiques }}$, Flammarion, Paris, 2013, 379 p.

20. J.-J. Rousseau, Rêveries du promeneur solitaire, 1776-1778

21. H.D. Thoreau, Walden; or, Life in the woods, 1854

22. A. Rey, Le Robert, dictionnaire historique de la langue française, Dictionnaires Le Robert, Paris, 2000, p. 754

23. A. Rey, Le Robert, dictionnaire historique de la langue française, Dictionnaires Le Robert, Paris, 2000, p. 700

24. Lucrèce, De la nature, Henri Clouard (Ed.), GarnierFlammarion, Paris, 1964, 243 p.

25. Pline l'Ancien, Histoire naturelle, nrf, St. Schmitt (Ed.), Gallimard 2013, 2127 p. initial publication in 77 or 78 under the name of Caii Plinii Secundi Naturalis historiae

26. Aristotle, Physics, 350 B.C.E, Translated by R.P. Hardie and R.K. Gaye

27. Histoires des émotions, Seuil, edited by A. Corbin, J.-J. Courtine, G. Vigarello, 3 vol., 2016-2017

28. A. Corbin, Les émotions individuelles et le temps qu'il fait, 43-56, in: A. Corbin, J.-J. Courtine, G. Vigarello (Eds.), Histoires des émotions: des lumières à la fin du XIX ${ }^{\mathrm{e}}$ siècle, Seuil, Paris, 2016, 470 p., vol. 2

29. S. Briffaud, Face au spectacle de la nature, 57-78, in: A. Corbin, J.-J. Courtine, G. Vigarello (Eds.), Histoires des émotions: des lumières à la fin du $\mathrm{XIX}^{\mathrm{e}}$ siècle, Seuil, Paris, 2016, 470 p. vol. 2

30. A. Vasak, Grandes émotions météorologiques, 79-97, in: A. Corbin, J.-J. Courtine, G. Vigarello (Eds.), Histoires des émotions : des lumières à la fin $\mathrm{du} \mathrm{XIX}^{\mathrm{e}}$ siècle, Seuil, Paris, 2016, 470 p., vol. 2

31. E. Baratay, S'émouvoir des animaux, 165-181, in: A. Corbin, J.-J. Courtine, G. Vigarello (Eds.), Histoires des émotions, De la fin du XIX ${ }^{\mathrm{e}}$ siècle à nos jours : des lumières à la fin du XIX ${ }^{\mathrm{e}}$ siècle, Seuil, Paris, 2017, 609 p. vol. 3 
32. S. Venayre, Transports affectifs : le voyage, entre émerveillement et déception, 182-195, in: A. Corbin, J.-J. Courtine, G. Vigarello (Eds.), Histoires des émotions, De la fin du XIX ${ }^{\mathrm{e}}$ siècle à nos jours : des lumières à la fin du XIX ${ }^{\mathrm{e}}$ siècle, Seuil, Paris, 2017, 609 p., vol. 3

33. C.F. Mathis, La terre vaine: mutations du sentiment de la nature, 196-209, in: A. Corbin, J.-J. Courtine, G. Vigarello (Eds.), Histoires des émotions, De la fin du XIX ${ }^{\mathrm{e}}$ siècle à nos jours : des lumières à la fin du XIX ${ }^{\mathrm{e}}$ siècle, Seuil, Paris, 2017, 609 p., vol. 3

34. J.-J. Rousseau, Du contrat social, ou principes du droit politique, 1758-1761

35. Levi-Strauss, La pensée sauvag, Plon, 1962, 349 p.

36. M. Serres, Le contrat naturel, Champs ${ }^{\text {classiques }}$, Flammarion, 1992, 191 p., initial publication 1990

37. A. Leopold, A Sand County Almanac, Oxford University Press, 1949

38. NPS Organic Act Overview, nature.nps.gov., National Park Service. 17 January 2007, Archived from the original on 6 February 2017, Retrieved 26 February 2017

39. https://www.iucn.org, accessed on 21 April, 2018

40. List of national parks, Available from https://en.wikipedia. org/wiki/List_of_national_parks, accessed on 21 April,

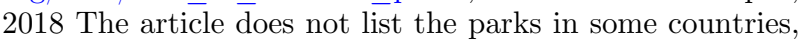
like China

41. R. Dumont, L'Afrique noire est mal parti, Le Seuil, Paris, 1962, coll. «Esprit », new edition, 2012

42. R. Carson, Silent Spring, Mariner Books, Boston, New York, 1962, 378 p., new edition 2002

43. P.R. Ehrlich, The Population Bomb, Ballantine Books, New York, 1968

44. P.R. Ehrlich, J.P. Holdren, Impact of population growth, Science, New Series 171(3977), 1212 (1971)

45. Christopher Belshaw, Environmental philosophy, Acumen, Chesham, 2001, ISBN 1-902683-21-8

46. Philosophy of environment, Available from https://en. wikipedia.org/wiki/Philosophy of environment, accessed on 21 April, 2018

47. R. Dawkins, The selfish gene, Odile Jacob, Paris, 1976

48. J. Lovelock, The ages of Gaia: A biography of our living earth, W. W. Norton \& Co, Oxford, 1995

49. A. Brennan, Yeuk-Sze Lo, Environmental Ethics, The Stanford Encyclopedia of Philosophy, Edward N. Zalta (Ed.), winter 2016 edition Available from https://plato.stanford.edu/ archives/win2016/entries/ethics-environmental/

50. ISEE-International Society for Environmental Ethics, Advancing the Field of Environmental Ethics and Philosophy since1990, Available from https://enviroethics.org/ syllabi/, accessed on 21 April, 2018

51. Aristotle, Politics, Bk. 1, Ch. 8

52. The Bible, King's James version, Genesis 1:26/28 and 29

53. S. Leigh Anderson, Asimov's "Three laws of robotics" and machine metaethics, Association For The Advancement Of Artificial Intelligence, Symposium Fall 2005, Available from https: / www.aaai.org/Papers/Symposia/Fall/2005/FS-0506/FS05-06-002.pdf

54. M.J. Zimmerman, Intrinsic vs. Extrinsic Value, The Stanford encyclopedia of philosophy, E.N. Zalta (Ed.), spring 2015 edition, Available from https://plato.stanford. edu/archives/spr2015/entries/value-intrinsic-extrinsic/

55. Schultz, Barton, Henry Sidgwick, The Stanford Encyclopedia of Philosophy, Edward N. Zalta (Ed.), summer 2015 Edition Available from https://plato.stanford.edu/archives/ sum2015/entries/sidgwick/
56. R. Routley, V. Routley, Human Chauvinism and Environmental Ethics, in: D. Mannison, M.A. McRobbie, R. Routley (Eds.), Environmental Philosophy, Australian National University, Research School of Social Sciences, Canberra, 1980, pp. 96-189

57. C. Stone, Should trees have standing? Southern California Law Rev., 45, 450 (1972) and reprinted in Schmidtz and Willott, Environmental Ethics: What really matters, what really works, Oxford University Press, New York, 2002

58. J. Feinberg, The rights of animals and unborn generations, in: W.T. Blackstone (Ed.), Philosophy and Environmental Crisis, University of Georgia Press, Athens, 1974, pp. 43-68

59. J.-P. Birat, Chapter 1: Introduction-man and nature, in: Environment and Society, sustainability materials science, EDP Science, Paris, to be published in 2019

60. A. Næss, The shallow and the deep, long-range ecology movement, inquiry, 16, 1973, reprinted in sessions 1995, pp. $151-155$

61. B. Latour, Reassembling the social: An introduction to actor-network-theory, Oxford university press, 2005

62. C. Merchant, The death of nature; woman, ecology and the scientific revolution, New York, Paperback, 1980

63. C. Merchant, The violence of impediments, Francis Bacon and the origins of experimentation, Isis 99, 731 (2008)

64. F. Bacon, The masculine birth of time-The great instauration of the dominion of man over the universe, 1602-1603

65. P. Pesic, Proteus rebound: Reconsidering the torture of nature, Isis 98, 304 (2008)

66. See footnote 9 in [63], which refers to the neo-Marxist Frankfurt School philosophers

67. S. Collins, A different heaven and earth, Judson Press, Valley Forge, 1974

68. M. Horkheiner, T. Adorno, Dialectic of enlightenment, trans. J. Cumming, Seabury Press, New York, 1979

69. M. Bookchin, Toward an ecological society, Black Rose Books, Montreal, 1980

70. N. Stern, Stern review: The economics of climate change, 30 October 2006, $662 \mathrm{p}$.

71. TEEB, Available from eb.org/our-publications/teeb-studyreports/ecological-and-economic-foundations/\#.Ujr1xH9 mOG8

72. M. Sagoff, Animal liberation and environmental ethics: Bad marriage, quick divorce, Osgoode Hall Law J. 22, 297 (1984)

73. P. Singer, Animal Liberation Random House, New York, 1975

74. T. Regan, The case for animal rights, Routledge BT and Kegan Paul, London, 1983

75. J. Baird Callicott, Animal liberation, a triangular affair, 1980, reprinted in Callicott 1989, pp. 15-38

76. R. King, Environmental ethics and the built environment, Environ. Ethics 22, 115 (2000)

77. R.J.H. King, Toward an ethics of the domesticated environment, Philos. Geogr. 6(1), 3 (2003)

78. A. Light, The urban blindspot in environmental ethics, Environ. Politics 10, 7 (2001)

79. C. Palmer, Placing animals in urban environmental ethics, J. Soc. Philos. 34, 64 (2003)

80. W. Fox, A theory of general ethics: human relationships, nature and the built environment, MIT Press, Cambridge, Mass, 2007

81. M. Serres, Le mal propre: polluer pour s'approprier?, Le Pommier, Paris, 2008, 92 p. 
82. Report of the World Commission on Environment and Development: "our common future", annex to the A/42/427 document to the Secretary General of the General Assembly of the United Nations, 4 August 1987

83. J. Stuart Mill, Principles of political economy, IV. 6 1, 1848, in: J.M. Robson (Ed.), Collected works of John Stuart Mill, University of Toronto Press, Toronto, 1963, vol. 2-3

84. D. Meadows, D. Meadows, J. Randers, W.W. Behrens III, Club of Rome, The limits of growth, 1972

85. G. Hardin, The tragedy of the commons, Science 162(3859), $1243(1968)$

86. S.M. Gardiner, A perfect moral storm: Climate change, intergenerational ethics and the problem of moral corruption, Environ. Values 15, 397 (2006)

87. Réchauffement climatique : le «j'accuse» de Bruno Latour, Obs, 15 octobre 2017, Disponible sur https://bibliobs. nouvelobs.com/idees/20171013.OBS5970/rechauffementclimatique-le-j-accuse-de-bruno-latour.html

88. H. Rolston, Feeding people versus saving nature? in: W. Aiken, H. LaFollette (Eds.), World hunger and morality, Prentice Hall, Englewood Cliffs, 1996, pp. 248-267

89. H. Jonas, Das Prinzip Verantwortung, Insel Verlag, Frankfurt a. M., 1979, French translation: Le principe responsabilité, Champ ${ }^{\text {Essais, }}$ Flammarion, Paris, 1995, $470 \mathrm{p}$.

90. J.-P. Birat, A. Carvallo Aceves, Territorial sustainability footprint, Rev. Métall. 109, 323 (2012)

91. Ulrich Beck, Risiko Gesellshaft, Auf dem Weg in eine adere Moderne, 31 January 1986, Frankfurt a. M. 2008 French edition, La société du risque, Sur la voie d'une autre modernité, Champs essais, Flammarion, 2008, 521 p., with a foreword by Bruno Latour

92. John Paul II, Address of His Holiness Pope John Paul II to the Conference on Environment and Health, 24 March 1997, https://w2.vatican.va/content/john-paul-ii/en/speeches/ $1997 / \mathrm{march} /$ documents/hf_jp-ii_spe_19970324_am biente-salute.html

93. Pope Francis, Encyclical Letter Laudato Si' of the Holy Father Francis on care for our common home, Vatican Press, 24 May 2015, 179 p.

94. J. Morand-Deviller, Le droit de l'environnement, PUF, Que sais-je, $\mathrm{n}^{\mathrm{o}} 2334$, 11th edition, 2015, $127 \mathrm{p}$.
95. Report of the United Nations Conference on Human Environnent, Chapter I-Declaration of the United Nations Conference on the Human Environment, principle 1, Stockholm, 5-16 June 1972, A/CONF.48/14/Rev.1

96. Report of the United Nations Conference on Human Environnent, Chapter I-Declaration of the United Nations Conference on the Human Environment, principle 2, Stockholm, 5-16 June 1972, A/CONF.48/14/Rev.1

97. Report of the United Nations Conference on Environment and Development, Rio de Janeiro, 3-14 June 1992, Annex I, Rio Declaration on Environment and Development, A/ CONF.151/26 (Vol. I), Available from http://www.un.org/ documents/ga/conf151/aconf15126-1annex1.htm

98. United Nations, data base on ecological legislation, ECOLEX, Available from https://www.ecolex.org

99. J.-P. Birat, Society, Chapter 15: Global and local environmental issues - emissions and pollution, EDP Science, 2018, two volumes, $750 \mathrm{p}$.

100. Code de l'environnement, France, 2000, Disponible sur https://www.legifrance.gouv.fr/affichCode.do?cidTexte= LEGITEXT000006074220

101. Environmental code, Sweden, 1998, Available from http:// www.government.se/legal-documents/2000/08/ds-200061/

102. J.-P. Birat, Life Cycle Assessment (LCA) and related methodologies, part of chapter XII in "Treatise on process metallurgy", in: Seshadri Seetharaman (Ed.), Elsevier, Amsterdam, 2013, 25 p.

103. Social Life Cycle Assessment (S-LCA), Life Cycle Initiative, accessed on 13 May 2018, Available from https://www. lifecycleinitiative.org/starting-life-cycle-thinking/life-cycleapproaches/social-lca/

104. Göran Finnveden, Valuation Methods Within LCA - Where are the values? Int. J. LCA 2(3), 163 (1997)

105. H.A. Udo de Haes, O. Jolliet, G. Finnveden, M. Hauschild, W. Krewitt, R. Müller-Wenk, Best available practice regarding impact categories and category indicators in life cycle impact assessment, 1999, Background document for the second working group on Life Cycle Impact Assessment of SETAC-Europe

106. J.-P. Birat, Sustainable materials science, 可持续的材料科 学—绿色冶金, USTB, Beijing, 2016-2018

107. K. Grandstand Gervais, Redefining Death Jul 01, 1987

Cite this article as: Jean-Pierre Birat, The environment and materials, from the standpoints of ethics, social sciences, law and politics, Matériaux \& Techniques 107, 102 (2019) 